\title{
ENSURING OF THE INSTITUTIONAL STATUS OF THE STATE UNDER GLOBAL CHALLENGES
}

\author{
Larysa Zhukova ${ }^{1}$
}

\begin{abstract}
The purpose of the article is a study of the theoretical and methodological aspects of ensuring the institutional status of the state under global challenges. Methodology. The scientific search for changes in the institutional status of the state has been carried out on the basis of classical, neoclassical and institutional methodology. On the basis of classical methodology, general theoretical approaches to discovering alternative options for ensuring the institutional status of the state in the economy have been clarified using the tools of dialectical analysis and synthesis. Structural and functional method based on systemic analysis has made it possible to formulate the author's vision about the contradictory impact of global challenges on the institutional status of the state. Institutional and neoclassical approaches have made it possible to analyze the factors of manifestation of the contradictory nature of the state in the economy. The results of the study have shown that, to date, there is still no effective institutional system in place in Ukraine that would ensure optimal use of economic potential and could form the basis of public consensus on strategic goals of socio-economic development. All this negates the effectiveness of measures to identify alternatives to the development of the institutional status of the state and to find ways to preserve national identity under globalization. The practical implication is to identify the priorities and directions of the state's regulatory capacity under growing socio-institutional gaps to maintain macroeconomic stability and an effective system to counteract destructive exogenous influences clearly. When choosing possible alternatives, the desire for economic efficiency and social justice of the society, ensuring sustainable development, which does not worsen the conditions and opportunities for future generations, should remain the leading idea of strengthening the institutional status of the state. Value/originality. During the research, it has been proved that one of the priority tasks of the state should be a radical change of the vector of socio-economic development and carrying out of urgent institutional reforms. In view of this, the fundamental ambiguity of global development paths requires the state to tackle the challenge of preserving and strengthening national subjectivity as a key condition for Ukraine's security and sustainable development. Connecting the tools and resources of innovative development to the problem can contribute to the long-term strengthening of national competitiveness and the strengthening of the institutional status of the state. The reliability of the work of all public institutes, the extension of technological freedom of economic entities and the safety of the functioning of the whole socio-economic system depend on the key position of the economic power of the state.
\end{abstract}

Key words: state, economic development, institutional status of the state, institutional changes, global challenges.

JEL Classification: E02, O11, P43

\section{Introduction}

The deepening of the contradictions of the development of the modern economy against the background of exacerbation of global transformational changes at different levels of the economic system actualizes the decisions of fundamental questions of the institutional status of the state. In this regard, the economic research of ensuring the institutional status of the state in conditions of socio-economic instability becomes extremely important.
Today, there is still no effective institutional system in place in Ukraine that would ensure optimal use of the national economic potential and could form the basis of public consensus on strategic goals of socio-economic development.

Awareness of the peculiarities and radical nature of the institutional changes that have been made dictates to the society the need to develop a different behavior model, both economic agents and authorities, and requires a change in the priorities of their interaction.

\footnotetext{
Corresponding author:

${ }^{1}$ V.N. Karazin Kharkiv National University, Ukraine.

E-mail: lnzhukova16@gmail.com

ORCID: http://orcid.org/0000-0003-2765-5544
} 
Establishing and enforcing civilized rules and regulations is of paramount importance for all participants in the economic system, as it determines the further sustainable development of our state's economy.

Modern economic science has recently linked the institutional status of the state not only to the level of socio-economic development, but also to the potential and real opportunities for its enhancement. Therefore, the study of the institutional status of the state is quite relevant task in both scientific-theoretical and practical aspects.

The purpose of the article is a research of the theoretical and methodological aspects of ensuring the institutional status of the state under global challenges.

The scientific search for changes in the institutional status of the state has been carried out on the basis of classical, neoclassical and institutional methodology. On the basis of classical methodology, general theoretical approaches to discovering alternative options for ensuring the institutional status of the state in the economy have been clarified using the tools of dialectical analysis and synthesis. Structural and functional method based on systemic analysis has made it possible to formulate the author's vision about the contradictory impact of global challenges on the institutional status of the state. Institutional and neoclassical approaches have made it possible to analyze the factors of manifestation of the contradictory nature of the state in the economy.

\section{Theoretical approaches to the analysis of the institutional status of the state}

Given that the crisis phenomena have identified the shortcomings and gaps of the existing theoretical paradigm in economic development and have outlined the likely threats to national sovereignty of states, the issue of identifying alternative concepts of developing the institutional status of the state and finding ways to preserve national identity are of particular relevance.

The tendencies of development of the institutional status of the state under globalization are covered in the works of such foreign researchers as: L. Britton, I. Clark, E. Kofman, S. D. Krasner, M. Newman, R. Robertson, M. Fowler, J. H. Franklin, M. Fritzler and others. Various aspects of the study of problems of realization of the institutional status of the state under deepening integration and globalization of the economy have been reflected in the works of a number of leading domestic scientists, in particular V. Heiets (justification of the ways of institutional and structural transformations in the economy of the state in the context of the evaluation of alternative variants of development), A. Hrytsenko (institutional architectonics and the search for alternatives to strengthening the institutional status of the state), P. Yeshchenko (transformation of economic relations and alternatives ways of the institutional changes under global changes), V. Sidenko (the impact of economic integration on the institutional status), O. Yaremenko (institutional foundations of alternative choices of a national model of economic development) and others.

\section{Research on the category of the concept of "institutional status of the state"}

Obviously, the most effective institute capable of forming and maintaining the stability of the national economy (the ability to maintain its structure and functional features during a certain interval despite external and internal shocks) is the institute of the state. As V. Osetskyi notes: "The Institute of State is a relatively separate part of its mechanism, which has the characteristics of an institutional status and a certain autonomy" (Osetskyi, 2016). By means of economic rules, each entity acquires its own institutional and economic status. Category "status" can mean a condition, position, establishment, which implies a certain static condition of the subject, the condition is outlined, defined (Yakovlev, 1988).

The process of forming an institute and acquiring, in fact, an institutional status is a process of formalizing social relations, moving from informal relations and unorganized activity to creating organizational structures with a clear hierarchy of power, taking into account the regulation of the activity of individuals and their relationships, juridical legalization of organizational structures, if available and necessary (Stopin, 2001).

The specificity of the institutional status of the state lies in the possibility of "self-institutionalization", that is, in granting the attribute of legitimacy to other institutes, in managing (within certain limits) the pace and stages of institutional transformation.

Institutional status determines the place of the entity in the economic structure, relationships, rights, responsibilities in relation to other entities. Formation of institutional status requires social, economic and individual (obligations to pay taxes or obtain necessary permits, to comply with public order) transaction costs. The mentioned costs should offset the social costs of establishing such institutional status. Ultimately, they should be identical. Accordingly, a society where the public and individual costs of institutional status coincide, or at least have slight variations, can be considered normal. In the case of a larger difference in the amount of expenditures, the inefficient state of resource allocation in society is obvious (Hrytsenko, 2007).

With these considerations in mind, let us define that the institutional status of the state is a theoretical concept that reflects the state's ability to embody the valueinstitutional foundations of the socio-economic system (solidarity, justice, cooperation, equality and hierarchy, equivalence and reciprocity); exclusive powers of the state to formulate institutional rules and norms and 
enforce them (exclusive right to violence, separation of powers, judiciary, monetary issue and ensuring trust in money, fiscal system, property institutions and their protection); the limits and nature of the subordination of the state itself to the mandatory institutional rules and regulations (judicial procedure for resolving disputes between the state and citizens, the obligation to provide social guarantees, following the principle: the state can only do what is allowed by law).

\section{Search for alternatives to the realization of the institutional status of the state}

Against the background of exacerbation of global imbalances and crisis phenomena, the scientific discourse on the regulatory capacity of the state under growing socio-institutional gaps to maintain macroeconomic stability and an effective system of counteracting destructive exogenous influences has been significantly actualized. In view of this, the important conditions for the institutionalization of secure economic development are the formation of a certain economic and institutional status by the state, that is, a set of rules and regulations that allow each entity to perform a certain economic role. Granting status, on the one hand, frees subjects from the uncertainty of their actions, extends their economic freedom and provides opportunities for accelerated development. On the other hand, due to its status, the state involves economic agents in the area of joint responsibility by overseeing, regulating and controlling their behavior to prevent deflection (Shevchenko, 2009). That is, the analysis of the institutional status of the state is obligatory for understanding the complex transformational processes, crisis phenomena, when the clear functional specialization of certain elements of the economy is broken and the factors that usually go beyond the subject of economic science begin to play a decisive role (Yaremenko, 1997).

Therefore, it becomes too difficult to choose possible alternatives, but the desire for economic efficiency and social justice, ensuring sustainable development, which does not worsen the conditions and opportunities for future generations, should remain the leading idea of strengthening the institutional status of the state. Thus, one of the primary tasks of the state is a radical change in the vector of socio-economic development and the implementation of urgent institutional reforms.

\section{Review methodology}

In today's environment of increasing global competition, a strategy of "gradual change" is becoming crucial in Ukraine. Along with the implementation of fundamental institutional reforms, the task of developing and implementing national programs for achieving social stability as a basis for ensuring the institutional status of the state is at the forefront. As V. Lahutin emphasizes, these national programs (shadowing the economy, overcoming corruption, deoligarchization, protecting property rights, overcoming the fictitious nature of the financial sphere) should form an effective system of anti-crisis measures that will not allow the uncontrolled development of society (Lahutin, 2017).

The process of integration of Ukraine into the environment of global competition calls for orientation on an innovative model of development, that is, a model of competitive behavior of a breakthrough nature. Institutional reforms aimed at concerted changes to rules and programs that form adequate conditions for access to resources and technology should be a condition for movement in this direction. In the context of accelerating global innovation in technology, it is unlikely to be able to catch up to the leaders, so, a "tunnel effect", when a country finds a technological niche that corresponds to the national socio-economic genotype, is a more realistic alternative in choosing a national innovation development strategy. Such a transition is most possible if the national economy relies on a model of endogenization of economic growth, which once has been substantiated at the Institute for Economics and Forecasting of the National Academy of Sciences of Ukraine (Heiets, 2003). The advantage of this endogenous model is the focus on the advanced development, which compels the state and business to seek criteria for the effectiveness of reforms in the field of mutual complement of state institutes and market institutions, which is impossible without careful use of the available institutional and value resources of society.

A national strategy for socio-economic development cannot be conservative. It is forced to be innovative, that is, oriented towards the inevitable change of environment, technology and institutes. The realities of the modern world lead to the search for innovative solutions and mechanisms of innovative development that ensure the institutional status of the state. Therefore, a coordinate system is needed, the economic basis of which will be a scientifically grounded strategy for the transition of the socio-economic system to a new technological model of development, which would be in the interests of the people and society as a whole.

The American scientist A. Toffler at one time pointed to the advent of the age of "industrialization" or the era of "knowledge and information technology". Currently, only a few countries are in transit and are able to move from the fifth to the sixth technological paradigm in the next 15-20 years. As for Ukraine, it is between the fourth and the fifth paradigm. The structure of the domestic economy is a symbiosis of industrial and post-industrial sectors of the economy. The main point, as A. Toffler pointed out, was to prepare the country for the big leap and also to reduce the negative consequences of collision with the "shock of the future" (Toffler, 2002). 
The entry of the Ukrainian economy into the technological trajectory of the evolution of human civilization requires increased attention to the knowledge-intensive industries, which will make it possible to build the type of economy where the sectors of technological materialization of knowledge will play a decisive role, and the production of knowledge will serve as a source of economic growth.

\section{Conclusions}

The particular complexity of the specific conditions of existence of the modern state structure is due to the fact that today there are many different perspectives and lines of development that may conflict with each other. In view of this, the fundamental ambiguity of global development paths requires the state to tackle the difficult challenge of preserving and strengthening national subjectivity as a key condition for Ukraine's security and sustainable development. Connecting the tools and resources of innovative development to the problem can broaden the scope of historical alternatives and contribute to the long-term strengthening of national competitiveness.

The reliability of the work of all public institutions, the extension of technological freedom of economic entities and the safety of the functioning of the whole socio-economic system, which should be based on the population of creative ideas for the approval of innovation-modernization development, depend on the key position of the economic power of the state.
Today, the technological subjectivity of Ukraine can be seen as a prerequisite for the realization of economic sovereignty and strengthening of the institutional status of the state. In turn, ensuring sustainable economic development of the state is impossible without institutional transformation and providing policy of constructive change.

Firstly, the further dynamics of the institutional status of the state, based on a series of changes and reforms, should involve close cooperation between the private and public sectors of the economy. In order to do this, private businesses and government agencies need to adopt a new format for cooperation in order to increase national competitiveness.

Secondly, it is necessary to dramatically change the vectors in the state's policy on realizing the potential of the regions on the way to forming a single European space.

Thirdly, overcoming threats to the labor resources security of the country, which are caused by demographic challenges (rapid aging of the population, mass unemployment of persons of working age, migration, internal displacement of persons).

Fourthly, the development and further reform of high-potential branches of economy.

Therefore, the Ukrainian economy can succeed if the authorities engage in dialogue with the people and the reforms, in turn, are comprehensive and decisive. It is this process that will promote the norms of democracy, the rule of law, human rights and freedoms in Ukraine, as well as accelerated economic development.

\section{References:}

Heiets, V. M., \& Skrypnychenko, M. I. (2003). Vid ekzoghenno zalezhnoji do endoghenno orijentovanoji strateghiji rozvytku ekonomiky [From exogenously dependent to endogenously oriented economic development strategy]. Ekonomika ta proghnozuvannja, no. 1, pp. 34-46.

Hrytsenko, S. A. (2007). Ekonomicheskie prestupleniia kak institutsyonalnye deviatsyi [Economic crimes as institutional deviations]. Nauchnye trudy DonNTU, vol. 31-3(117), pp. 17-21.

Lahutin, V. D. (2017). Stabiljnistj suspiljnogho rozvytku: dosvid mizhdyscyplinarnogho doslidzhennja [Stability of social development: experience of interdisciplinary research]. Ekonomichna teorija, no. 2, pp. 5-18.

Osecjkyj, V. L. (2016). Upravlinnja vlasnistju jak umova posylennja funkcij derzhavy: instytucijnyj kontekst [Property management as a condition for strengthening state functions: an institutional context]. Naukovyj poghljad: ekonomika ta upravlinnja, no. 1(55), pp. 61-68.

Shevchenko, L. S., Ghrycenko, O. A., \& Makukha, S. M. (2009). Ekonomichna bezpeka derzhavy: sutnistj ta naprjamy formuvannja [Economic security of the state: essence and directions of formation]. Kharkov: Pravo. (in Ukrainian) Stepyn, V. S. (ed.) (2001). Novaya fylosofskaya entsyklopedyya [New philosophical encyclopedia]. Moscow: Mysl'. Toffler, E. (2002). Shok budushcheho [Future shock]. Moscow: Yzdatel'stvo - AST. (in Russian)

Yakovlev, A. M. (1988). Sotsyolohyya ekonomycheskoy prestupnosty [Sociology of Economic Crime]. Moscow: Nauka. (in Russian)

Yaremenko, O. L. (1997). Institutsyonalnye osnovaniia perehodnyh protsesov v ekonomike [Institutional foundations of transition processes in the economy] (PhD Thesis). Kharkov: Kharkov State University of Maxim Gorky. 